\title{
Hungarian referendum on distribution of migration quotas. What about the European solidarity? ${ }^{1}$
}

\section{Introduction}

The principle of solidarity in the European Union is one of the fundamental norms of the EU and is understood as an incentive for the creation of social bonds among the Europeans and for the European unity, unity of generations and solidarity among Member States (Ross, 2018, p. 5). The European solidarity is perceived as a fundamental norm "based on sharing both the advantages, i.e. prosperity, and the burdens equally and justly among members" (Solidarity principle, 2011). The European Treaties explicitly refer to this fundamental principle in many provisions, including the values (Art. 2 TEU) or objectives of the European Union (Art. 3 TEU) and particular policies where the 'principle' or 'spirit' of solidarity is to be applied (Eg Arts 80, 122 and 194 TFEU). Thus, we may state that so called idea of European solidarity is present in the legal framework of the EU, as well as a well-established constitutional tradition in some Member States (Ross, 2018, p. 5).

The debate devoted to European solidarity saw a significant boost since 2008, when many European countries (see: Spain, Italy, Portugal, Greece) were hit by the global economic crisis (Kontochristou, Mascha, 2014, p. 50). The EU Member States from the South of Europe have been mostly affected by the economic and financial crisis. Undoubtedly, their governments efforts to minimalize the consequences of the crisis have led to deep institutional changes and turning points for the welfare state or labor relations. The Eurozone crisis has left Greece in a biggest recession ever. It seems, since 2010 the EU has been facing the worst economic crises in its history. "At the same time, Europe has been flooded with millions of migrants and refugees fleeing conflicts in Syria, Afghanistan, and Iraq, triggering strong domestic opposition and straining the economic and political resources of EU member-states" (Europe in Crisis...).

Three years since the peak of the crisis, there are many opinions that the biggest in Union's history migration crisis still threatens to ruin the EU.

In spite of the fact that the numbers have sharply dropped down from their peak in 2015-2016, tens of thousands of people are still trying to reach Europe. "Many observers believe it is only a matter of time before the number of arrivals picks up signifi-

${ }^{1}$ This article is a part of a research prepared under a project "Common Values! Arguments, Counterarguments and Courses of Action in the German and Polish European Policy" realized by European Academy Berlin in co-operation with the AdamMickiewicz University in Poznań. More in: Musiał-Karg, 2017. 
cantly once more" (Henley, 2018). The fact is that the European Union, as well as the countries affected by the migration problem, have tried to take preventive measures, but neither the agreement with Turkey, nor the new border fence in the Balkans, nor the bilateral agreement between Italy and Libya - have not guaranteed the improvement of the situation. Without any doubt the European Member States have to solve that migration problem and do their best to overcome the crisis, and Europe needs to look closely at its asylum and immigration regulations. „At present Spain, Italy and Greece take most of the strain owing to their geographical position on the Mediterranean Sea and the fact that, under EU law, asylum seekers must lodge their applications in the first EU country they enter" (Henley, 2018).

However, the governments of the EU MS are still looking for solutions that would satisfy the Community and would minimize the negative effects of the migration waves. Some of the states discuss better and more effective distribution of migration quotas, while other governments want to provide tougher control of external borders of the EU. It seems that the Union has a multidimensional problem. It needs to balance: on one hand the desirable solutions of the southern states (which are in the first line of migration), and in other hand - measures to secure the countries of wealthy North, which are often the final destination. It is also important to remember about the fact that there are also countries that do not agree with solutions proposed or suggested by the European Union. In this group there are both Poland and Hungary that refuse to accept migrants on their territory.

The migration crisis has shown a serious split over understanding of fundamental values of the European Union. The standpoints of some of the EU Member States (for instance: the Visegrad Group countries) have exhibited that the solidarity is defined in different way than for example in Germany. The referendum of October 2016 initiated by the Hungarian government has been described as the national referendum against the European solidarity (Neillssen Raynold, 2016). The vote has been also interpreted as a very serious misuse of direct democracy, since Hungarian Prime Minister employed referendum to realize his political goals (Werner-Mueller, 2016). The referendum campaign has been criticiced of its very poor standards of democratic debate. Hungarian government has argued that migration crisis and UE's attempts of coping with it have showed disrespectfulness of the Union towards the Hungarians' needs (Diószegi-Horváth, 2016).

\section{Methodological remarks}

The practice of using direct democracy instruments in the European Union's countries shows that, alongside numerous referenda held on matters of the state, "European" issues are becoming an increasingly popular subject of public debate followed by voting. Using a national referendum to make decisions pertaining to the process of European integration is far from being a new phenomenon since a first such referendum was held as early as 1972. Since then, European integration has been the subject of nearly sixty national referenda in EU member states, candidate countries and in third countries bound with the European Union by all kinds of bilateral agree- 
ments (Switzerland, Liechtenstein). Although the majority of experiences gathered in the process of holding referenda on "European" issues are apparently positive, there have also been cases when referenda generated problems both for member states and the European Union.

The experiences with direct democratic instruments in the EU Member States show that "European" issues have become an increasingly popular and often - controversial subject of public debate and then of referenda. The stimulus to deal with this topic were the experiences related with the 2016 Hungarian referendum on imposed quotas on migrant numbers. It hast to be added that Hungary was one of the affected countries during the European migrant crisis. The subject of the 2016 referendum was significant not only fort he Hungary itself, but also for other countries (Poland) and for the whole European Union. The referendum highlighted a paradox, that should be considered by the EU leaders: policy making in a variety of areas increasingly happens at the supranational level, while from the perspective of most citizens, "politics still play out overwhelmingly through a national perspective" (Garavoglia, 2016).

The main thesis proposed in this paper is that in recent years referenda have become very popular instruments for making decisions with respect to European crises (Grexit, Brexit, migration crisis), and the Hungarian vote seems to be one of them. One should remember that the 2016 referendum was devoted to a very difficult and socially important problem. It is argued that this national referendum was a maneuver of Hungarian Prime Minister Victor Orban against the European Union, its solidarity and common interests. The main objective of this paper is to answer the question about the course and consequences of Hungarian referendum of 2016 for the European Union and its values, as well as about the prospects for further use of direct democratic tools to decide on European issues. The considerations lead in this article aim also at finding answers to the questions about the role of referendum on problematic / controversial issues in Hungary and about the factors impacting the voters decision. Having in mind that the migration crises should be treated as a joint challenge for the entire EU and all its member states should take a part of responsibility in seeking the proper solutions satisfying all MS - the author tries to analyse the Hungarian referendum in the context of the European solidarity value and in the context of instrumental use of direct democracy.

\section{Hungary's refugee referendum}

After the fall of the so called 'Iron Curtain' in 1990, Hungary's attitude to Europe was supported by a large domestic consensus. Hungary applied for EU membership in 1994. Negotiations opened in March 1998 and ended in December 2002. It should be noticed that joining the EU following its political, social and economic transformation was among the priorities of the foreign policy not of the Hungary, but also of the newly emerged democratic states in Central and Eastern Europe.

Accession to the EU was therefore commonly considered an important issue that did not address individual interests, but rather concerned the future of all citizens and generations to come. 
One should remember that in Hungary, there were two referenda held on European issues: the 2003 accession vote and 2016 vote on refugee quotas. In the first vote held on 12th April, 2003 - the Hungarians answered the question: "Do you accept that Hungary is to become a member of the European Union?" Although the referendum was not compulsory, its result was treated as a decisive one - Hungarian Prime Minister - Peter Medgyessy (Socialist Party, MSZP) - emphasized that popular support was absolutely necessary for him to be able to sign the accession treaty. Hungarians strongly supported their country's accession to the European Union ( $83.76 \%$ of voters saying "Yes" to the EU; $45.63 \%$ of turnout). It needs to be pointed out that quite visible impact on the referendum result had Fidesz party, that in the aftermath of the 2001 elections was moved from the government to the opposition, and in its so-called „yes, but" started to highlight the potential difficulties of the accession and European integration problems.

The 2016 Hungarian referendum was the second vote on issues related to the European integration processes. It was initiated by the government of Viktor Orbán, under the provision of article 8 of the national constitution.

The referendum was held on October 2, and was the outcome of the September 2015 decision made by EU member states to relocate 160,000 immigrants who entered Greece and Italy to other member states over a period of two years. The participation in the resettlement program was deemed to be obligatory, with every state having been allocated a number of refugees to admit.

According to press releases from the beginning of 2015 ca. 1,000 immigrants entered Hungary every week, mainly from Serbia and Hungarian police detained ca. 67,000 illegal immigrants (Orban broni ). As a consequence, on July 17, 2015, the Hungarian government decided to close the green border between Hungary and Serbia and put up a $4 \mathrm{~m}$ tall fence of $174 \mathrm{~km}$ in this section. This temporary fencing off was justified with the need to observe EU requirements and protect the external border of the Schengen zone from illegal immigrants from the south. Viktor Orbán did not rule out the possibility that a wall might be erected between two member states of Schengen zone - Hungary and Croatia (Orban nie wyklucza...).

Next to so called Grexit (English: Greek + exit: a term meaning the possibility of Greece leaving the euro zone due to the economic crisis in Greece) and Brexit (English: Britain + exit: the process of UK leaving the structures of the European Union, initiated by the referendum in June 2016), the immigration crisis has recently posed the greatest challenge to the European Union. This crisis can surely be described as a stimulus to reinforce internal solidarity and responsibility, and to intensify aid offered to the states facing the greatest risk of the influx of immigrants. After the decision taken in September 2015 by the European Union Council, followed by the decision of February 2016 on possible solutions to the immigration crisis, more and more voices could be heard saying that EU member states are not prepared to implement the activities planned. These decisions (and in particular the establishment of a permanent crisis relocation instrument for all member states) aroused opposition against admitting immigrants in some countries. Such resistance was particularly stressed by Hungary, the Czech Republic, Slovakia and Romania, whose delegates voted against the decision to relocate refugees in EU member states at a session of the Justice and Home Affairs 
Council on 22 September 2015. Unlike Poland and the Baltic States, who were also among the leading critics of the obligatory refugee quotas, Hungary, the Czech Republic, Slovakia and Romania demanded that decisions concerning the quotas were made on the basis of voluntary declarations by individual EU member states by the end of negotiations.

The states that were against the decisions made by the EU Council wanted, first and foremost, to strengthen the EU borders and curb the influx of immigrants. They believed that only after these priorities were achieved the issues of quotas should be discussed. 'In the states that oppose the obligatory quotas to be allocated the migration crisis is the main topic of public debate and almost all political circles have backed their governments' standpoints.' In Hungary, PM Viktor Orbán criticized 'German moral imperialism as concerns the migration crisis' on September 23 (Stasik, 2015) and stated that 'the EU should develop a special partnership with Russia and Turkey, who are crucial for the crisis to be resolved' (Gniazdowski, 2015). The immigration crisis has revealed problems with maintaining solidarity and responsibility inside the EU, and on account of the referendum held there Hungary has become a symbol of protest against EU policies adopted to solve the crisis.

It needs to be noted that according to a poll by the Pew Research Centre Hungary was one of the most xenophobic countries in Europe with $82 \%$ respondents stating that refugees would have a negative economic impact on Hungarian economy, which was a result of governmental billboard campain saying: "If you come to Hungary, you cannot take the jobs of Hungarians." The campaign alongside with the huge number of refugees that turned up on Hungarian borders in 2015 were the main factors influencing the popular attitudes towards migrants (Hajagos, 2016). In 2015 the Fidesz Party government started a billboard campaign, which presented manipulated messages: "Since the beginning of the migrant crisis, more than 300 people died in terror attacks" or "Did you know that the attack in Paris was carried out by immigrants?"

Political analysts Attila Juhász stated that the campaign were differentiated in terms of message to the society. The first campaign by the Hungarian government wanted to affect the minds of people with messages like the immigrants will take the jobs of Hungarians, and the further campaign was more emotional, "emphasizing a visceral fear, of crime and the fear of terrorism." It resulted in $75 \%$ Hungarians declaring their fear of terrorism. Juhász suggested also that the number of those fearing terrorism could rise more as the government created "a moral panic button" which it pushed as often as it could (Hajagos, 2016).

The government of Viktor Orbán initiated a referendum where voters were to answer the question of "Do you want the European Union to be able to prescribe the mandatory settlement of non-Hungarian citizens in Hungary even without the consent of Parliament?" For the referendum to be valid, voter turnout had to amount to at least $50 \%$ of the $8.27 \mathrm{mln}$ of eligible voters. This election threshold should be considered to be extremely high given the fact that voter turnout exceeded $50 \%$ only in two out of seven referenda held after 1989 (in 1989 and 2008). Even the participation in the above-mentioned symbolic referendum on accession of 2003 was lower than $50 \%$. 
Results of Hungarian migrant quota referendum held on 2 October 2016

\begin{tabular}{||l|c|c|}
\hline & Number of votes & Votes in \% \\
\hline Valid votes & $3,418,387$ & 93.8 \\
\hline "Yes" answers & 56,163 & 1.64 \\
\hline "No" answers & $3,362,224$ & 98.36 \\
\hline Total votes & \multicolumn{2}{|c|}{$3,643,055$} \\
\hline Registered voters & \multicolumn{2}{|c|}{$8,272,625$} \\
\hline Turnout & $\mathbf{4 4 . 0 4}$ \\
\hline
\end{tabular}

Source: https://static.valasztas.hu/dyn/onepsz201610/szavossz/en/eredind_e. html, 1.07.2019.

Hungarian Prime Minister - Viktor Orbán - frequently stated that the referendum would aid his efforts to tighten EU immigration policies. It seems, however, that he must have realized how difficult it would be to achieve the required voter turnout of $50 \%$, as he kept remarking that the referendum would evidence whether Hungarian society is a true community.

As announced, the government-initiated referendum took place on October 2, 2016. Given the results of the Brexit referendum and the unresolved migration crisis, the entire European community was watching the developments in Hungary and the results of the referendum there. $41.32 \%$ valid votes were cast, $98.36 \%$ of which said "No" to the referendum question. Only $1.64 \%$ of valid votes were for the quotas (National Election Office). Although the referendum was invalid, PM Viktor Orbán announced that amendments would be made to the Constitution on account of the desires of the majority of referendum participants who expressed a clear standpoint on the matter in question.

From the point of view of the whole European Union and individual member states, the second referendum, organized over a very short period of time in an EU member state, was a highly significant and carefully scrutinized event.

The Hungarian referendum, held shortly after the Brexit referendum in the United Kingdom, was another vote that produced a serious social schism. The vote initated by Orbán was the only popular vote on the issue of immigration quotas held in the European Union which was deeply divided by the immigration crisis. Orbán based his referendum campaign on populist and xenophobic language where refugees were identified with terrorists. The fear of refugees provided fuel to all kinds of populists. If this Hungarian experiment succeeds, extreme right-wing and populist parties in Europe will gain a strong argument in favor of closing borders. Eventually, the fundamental EU principle of unity, under which member states share not only power and prosperity but also challenges and problems, will be undermined (Pawlicki, 2016).

The analysis of the context of the Hungarian referendum that Orbán based on social fears of uncontrolled migration shows that its main purpose was to reinforce the Prime Minister's position in EU structures. Before the problem of the influx of illegal immigrants to the EU intensified, Viktor Orbán had little influence on EU policies. Initiating the referendum, he tried to impose a certain tone and direction of debate in the EU clearly manifesting his protest against Hungary admitting refugees to its territory. 'Brussels must be stopped. We can't allow them to force us [...] to import the bitter fruits of 
their mistaken immigration policies. We don't want to and won't import crime, terrorism, homophobia and anti-Semitism into Hungary' said Hungarian PM (Orban o UE...). The language of the government translated into social attitudes. According to a survey ${ }^{2}$ conducted by Pew Research in spring 2016, 82\% of Hungarians believed that refugees take away jobs and benefits, and $76 \%$ of respondents said that refugees increase the terrorist threat. It should be noted that the opinions of respondents to this survey in a majority of countries examined were similar to those in Hungary. In Hungary, Italy, Poland and Greece over half of respondents had negative opinions about Muslims (72\% in Hungary and $66 \%$ in Poland). The least negative opinions were recorded in Great Britain, Germany and France (28-29\%). In all the countries examined, people who declared right-wing attitudes were more prone to negative opinions about Muslims, they expressed greater concern with the influx of refugees and were against social diversity. Interestingly, the smallest proportion of opponents to social diversity was found in Great Britain, Sweden and Spain, where over $30 \%$ of respondents said that their countries are improving on account of diversity (Europejczycy: uchodźcy...).

\section{Concluding remarks}

The considerations presented in this article allow to draw the following conclusions on the outcomes of Hungarian referendum held in 2016, as well as on the role of referenda for the process of European integration:

- firstly, in the last years the European Union has been facing very serious crisises: they are not only of financial or economic nature, but also related Great Britain's decision to leave the EU or migration crisis. What is important in this context, some Member States decide to hold a referendum, which is treated as a panacea for crisis situations. As experiences show, sometimes the decisions made in the referendums may deepen the crisis - if not in a specific country, certainly in the European Union. Such situations occurred in 2005 after the referenda on so called „Constitution for Europe,” after the referendum related to Grexit, or after referendum on UK membership in the EU;

- secondly, the result of Hungarian referendum on immigration quotas should be interpreted as symptomatic of the increasing difficulties the EU is facing when agreeing on a joint standpoint on matters that are crucial for it. It is perceived as proof for the lack of common understanding of the solidarity among certain European Union Member States;

- thirdly, although the Hungarian referendum turned out to be Orbán's defeat to some extent, it may brought far-reaching consequences towards European foreign policy (in the context of the refugee crisis). The referendum was intended to ensure the Hungarian PM's strong position in the EU, making his voice on the issue of refugees louder;

- fourthly, the campaign launched by the government before the refugee quotas referendum was highly manipulative and aimed at creating the fear among misinformed Hungarian citizens (in the campaign Orban's government made a connection be-

2 The survey was conducted in April and May 2016 in Poland, Germany, Sweden, the Netherlands, Great Britain, France, Spain, Italy, Greece and Hungary. 
tween the migration crisis and the growth of terrorism in Europe. This could be a very important factor influencing the people's attitudes towards the migrants in Hungary;

- fifthly, the use of nationwide referendum in Hungary can be approached as a tactical move by government, desiring to exert pressure on the EU with respect to immigrants, among other problems. In the case of the Hungarian referendum, its results could be used by other governments manifesting different opinions (or protesting) about EU policies, and an incentive to submit the issue of admitting refugees to a popular vote. The European community could observe it in Visegrad countries, where tensions between the V4 and the EU started in 2015, after approval the quotas of relocation of the refugees;

- sixthly, analysis of the history of European integration demonstrates that referenda seem a significant instrument, applied to make decisions on difficult, often controversial and complicated matters that politicians feel uneasy about, and the process of European integration has long been (starting in 1972) a topic left to be decided about by societies in many countries. But one should also remember that some politicians treated the direct decision-making in a very instrumental way. With a very poor standards of Hungarian referendum campaign one may state that the 2016 referendum was a misuse of direct democracy. Democracy International - non-govermental organization which aims to strengthen citizens' participation via direct democracy - concluded that Victor Orbán used "the Hungarian people to legitimise his anti-EU and anti-refugee politics," Daniel Schilly - board member of Democracy International claimed that referendum was "contrary to the idea of direct democracy, which provides that citizens can initiate law proposals in order to counterbalance the politics of the majority. Prime Minister Orbán has triggered the top-down referendum, knowing that he has the majority of the Parliament behind him. He is blending the executive and legislative powers, and is allowing citizens simply to nod in agreement rather than act proactively" (Refugee vote...).

Concluding, it should be emphasized that nationwide referenda are a popular way to make decisions on European integration. Although such votes are frequently consultative and non-binding, the governments of individual states declare that they would respect the desires of their citizens and make decisions conforming to them. Although a majority of votes on European matters have typically facilitated expansion and deepened cooperation within the EU, the 2016 referendum offers an example of Hungary turning their backs on the EU and the principle of united implementation of EU policies. The referendum has become a component of debates about the need to change the European Union on the one hand and a crucial stimulus to apply concrete strategies to implement some vision of future EU development and overcome crises (such as the refugee crisis and its aftermath) on the other (Musiał-Karg, 2017).

Without any doubt, the referendum held in Hungary - has put the European Union's values to the test. It seems that they did not passed that examination.

One should bear in mind that on one hand direct democracy is a very virtuous way of making decision, and on the second hand referenda may bring also very dangerous consequences. From the perspective of European Union, the 2016 referendum seems to have brought rather disappointment (of solidarity deficit in the refugee crisis) and complications and challenges for the future. 


\section{Bibliography}

Diószegi-Horváth N. (2016), Fidesz is driving Hungarians into a dishonest referendum, 26.09.2016, https://www.boell.de/en/2016/09/26/fidesz-driving-hungarians-dishonest-referendum, 14.06.2019.

Europe in Crisis: Finance, Migration, Brexit and the Future of the European Union, http://europe. wisc.edu/events/europe-crisis-finance-migration-brexit, 5.01.2017.

Europejczycy: uchodźcy... oznaczaja wzrost terroryzmu, 12.07.2016, POLSATnews, http://www.polsatnews.pl/wiadomosc/2016-07-12/europejczycy-uchodzcy-oznaczaja-wzrost-terroryzmu, 05.03.2019.

Garavoglia M. (2016), What Hungary's referendum says about Europe's politics and policymaking, 3.10.2016, https://www.brookings.edu/blog/order-from-chaos/2016/10/03/what-hungarysreferendum-says-about-europes-politics-and-policymaking/, 13.12.2018.

Gniazdowski M., Czechy, Stowacja, Węgry i Rumunia: „nie” dla rozlokowania uchodźców, 23.09.2015, https://www.osw.waw.pl/pl/publikacje/analizy/2015-09-23/czechy-slowacjawegry-i-rumunia-nie-dla-rozlokowania-uchodzcow, 13.12.2018.

Hajagos A., Hungary, xenophobia and feeding the fears of terrorism, 21.07.2016, https://www. euronews.com/2016/07/21/hungary-xenophobia-and-feeding-the-fears-of-terrorism, 13.12.2018.

Henley J. (2018), What is the current state of the migration crisis in Europe?, 28.11.2018, "The Guardian“, https://www.theguardian.com/world/2018/jun/15/what-current-scale-migrationcrisis-europe-future-outlook, 05.06.2019.

Kontochristou M., Mascha E. (2014), The Euro Crisis and the Question of Solidarity in the European Union: Disclosures and Manifestations in the European Press, "Review of European Studies", vol. 6, no. 2, p. 50.

Musiał-Karg M. (2017), Direct democracy vs. European solidarity. British and Hungarian referendums of 2016, in: Common Values. Discussing German and Polish Perceptions of European Integration, ed. W. Priesmeyer-Tkocz, Nomos, Berlin.

National Election Office, 03.10.2016, https:/static.valasztas.hu/dyn/onepsz201610/szavossz/en/ eredind_e.html, 14.06.2019.

Neillssen Raynold D. C. (2016), National democracy vs. European solidarity: Hungary's referendum on refugees, 1.10.2016, http://www.katoikos.eu/analysis/national-democracy-vs-europeansolidarity-hungarys-referendum-on-refugees.html, 15.06.2019.

Orban broni płotu na granicy z Serbia, 1.07.2015, TVN24, http://www.tvn24.pl/wiadomosci-zeswiata,2/wegry-orban-twierdzi-ze-mur-na-granicy-z-serbia-jest-konieczny,556393.html, 15.06.2019.

Orban nie wyklucza budowy muru na granicy z Chorwacją. Węrzy odgrodzili się już od Serbii, 13.08.2018, TVP INFO, http://www.tvp.info/21490850/orban-nie-wyklucza-budowy-muruna-granicy-z-chorwacja-wegrzy-odgrodzili-sie-juz-od-serbii, 15.06.2019.

Orban o UE: nie przyjmiemy gorzkich owoców ich pomylonej polityki imigracyjnej, 29.02.2016, TVP INFO, http://www.tvp.info/24225079/orban-o-ue-nie-przyjmiemy-gorzkich-owocowich-pomylonej-polityki-imigracyjnej, 15.06.2019.

Pawlicki J. (30.09.2016), Dlaczego węierskie referendum ważne jest dla catej Europy, http:// www.newsweek.pl/opinie/referendum-na-wegrzech-dlaczego-jest-wazne-dla-calej-europy,artykuly,397874,1, 15.06.2019.

Refygee vote is misuse of direct democracy, 30.09.2019, Democracy International, https://www. democracy-international.org/hungary-referendum-refugees, 12.05.2019.

Ross M. (2018), Solidarity in Europe. Alive and Active, European Commission. Directorate-General for Research and Innovation, Brussels.

Solidarity principle, 4.05.2011, https://www.eurofound.europa.eu/observatories/eurwork/industrialrelations-dictionary/solidarity-principle, 15.06.2019. 
Stasik E., Orban zarzuca Niemcom “moralny imperializm”, 23.9.2015, http://www.dw.com/pl/orban-zarzuca-niemcom-moralny-imperializm/a-18735029, 15.06.2019.

Werner-Mueller J. (2016), Hungary's Refugee Referendum Is a Referendum on Europe's, Survival, 29.09.2016, https://foreignpolicy.com/2016/09/29/hungarys-refugee-referendum-is-a-referendum-on-europes-survival-orban-merkel-eu/, 14.06.2019.

\section{Summary}

In recent years national referenda have become popular instruments for making decisions on very problematic European issues (Grexit, Brexit, migration crisis). The Hungarian vote of 2016 on refugee quotas distribution seems to be one of them. Next to its importance in the Euopean context, the 2016 referendum was devoted to a very difficult and socially important problem. It is argued that this national referendum was a maneuver of Hungarian Prime Minister Victor Orban against the European Union, its solidarity and common interests. Having in mind that the migration crises should be treated as a joint challenge for the entire EU and all its member states should take a part of responsibility in seeking the proper solutions satisfying all MS - the main objective of this paper was to answer the question about the course and consequences of Hungarian referendum of 2016 for realization of the solidarity principle. The article aimed also at finding answers to the questions about the role of referendum on problematic/controversial issues in Hungary and about the factors impacting the voters decision.

Key words: referendum, Hungary, refugee crisis, solidarity in the European Union

\section{Węgierskie referendum w sprawie obowiązkowych kwot relokacji uchodźców. Co z tą europejską solidarnością?}

\section{Streszczenie}

W ostatnich latach krajowe referenda stały się popularnymi instrumentami podejmowania decyzji w bardzo problematycznych i kontrowersyjnych kwestiach (Grexit, Brexit, kryzys migracyjny). Węgierskie referendum w sprawie relokacji narzuconych przez UE kwot uchodźców jest jednym z przykładów takich głosowań. Oprócz kontekstu europejskiego, węgierskie referendum poświęcone było bardzo trudnemu i społecznie ważnemu zagadnieniu. Argumentuje się także, że głosowanie to było manewrem węgierskiego premiera Victora Orbana przeciwko Unii Europejskiej, jej solidarności i wspólnym interesom.

Pamiętając, że kryzysy migracyjne należy traktować jako wspólne wyzwanie dla całej UE, a wszystkie państwa członkowskie powinny wziąć na siebie odpowiedzialność za poszukiwanie właściwych rozwiązań satysfakcjonujących wszystkie państwa członkowskie - za główny cel niniejszego artykułu przyjęto udzielenie odpowiedzi na pytanie o rolę węgierskiego referendum z 2016 r. dla realizacji zasady solidarności w Europie. Rozważania prowadzone w artykule miały również na celu znalezienie odpowiedzi na pytania dotyczące roli referendum w problematycznych/ kontrowersyjnych kwestiach na Węgrzech oraz czynników wpływających na decyzję wyborców.

Słowa kluczowe: referendum, Węgry, kryzys uchodźczy, solidarność w Unii Europejskiej 